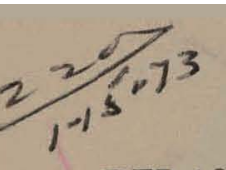

RFP-1974

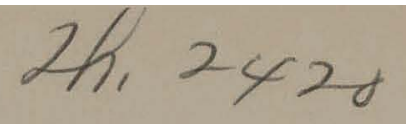

RFP-1974

December 26, 1972

\title{
QUANTITATIVE DETERMINATION OF MOISTURE
}

\section{BY THE COLD-TRAP METHOD}

Roger S. Cichorz

\section{Dow}

(a)

DOW CHEMICAL U.S.A.

ROCKY FLATS DIVISION

P. O. BOX 888

GOLDEN, COLORADO 80401

U.S. ATOMIC ENERGY COMMISSION

CONTRACT AT(29-1)-1106 


\section{DISCLAIMER}

This report was prepared as an account of work sponsored by an agency of the United States Government. Neither the United States Government nor any agency Thereof, nor any of their employees, makes any warranty, express or implied, or assumes any legal liability or responsibility for the accuracy, completeness, or usefulness of any information, apparatus, product, or process disclosed, or represents that its use would not infringe privately owned rights. Reference herein to any specific commercial product, process, or service by trade name, trademark, manufacturer, or otherwise does not necessarily constitute or imply its endorsement, recommendation, or favoring by the United States Government or any agency thereof. The views and opinions of authors expressed herein do not necessarily state or reflect those of the United States Government or any agency thereof. 


\section{DISCLAIMER}

Portions of this document may be illegible in electronic image products. Images are produced from the best available original document. 


\section{LEGAL NOTICE}

This report was prepared as an accuunl of work sponsored by the United States Government. Neither the United States nor the United States Atomic Energy Commission, nor any of their employees, nor any of their contractors, subcontractors, or their employees, makes any warranty, expressed or implied, or assumes any legal liability or responsibility for the accuracy, completeness or usefulness of any information, apparatus, product or process disclosed, or represents that its use would not infringe privately owned rights.

Printed in the United States of America

Available from the

National Technical Information Service

U. S. Department of Commerce

Springfield, Virginia 22151

Price: Printed Copy $\$ 3.00$; Microfiche $\$ 0.95$ 


\title{
QUANTITATIVE DETERMINATION OF MOISTURE BY THE COLD-TRAP METHOD
}

\author{
Roger S. Cichorz
}

\author{
Quality \\ MASS SPECTROMETRY LABORATORY
}

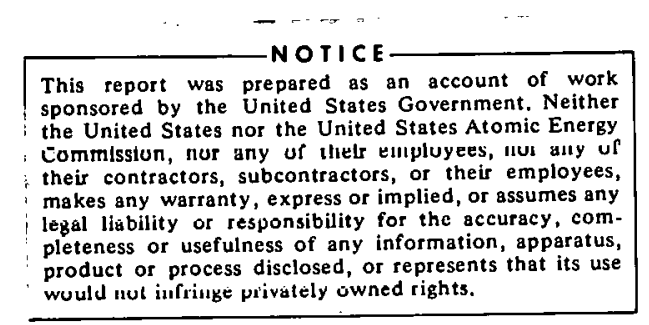

DOW CHEMICAL U.S.A. ROCKY FLATS DIVISION

P. O. BOX 888

GOLDEN, COLORADO 80401

Prepared under Contract AT(29-1)-1106 for the

Albuquerque Operations Office U.S. Atomic Energy Commission

SUBJECT DESCRIPTORS Cold-trap enalysis Quantitative analysis Analysis

Water Sampling Infrared spectrocoopy

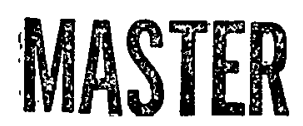


RFP-1974 
RFP-1974.

\section{CONTENT S}

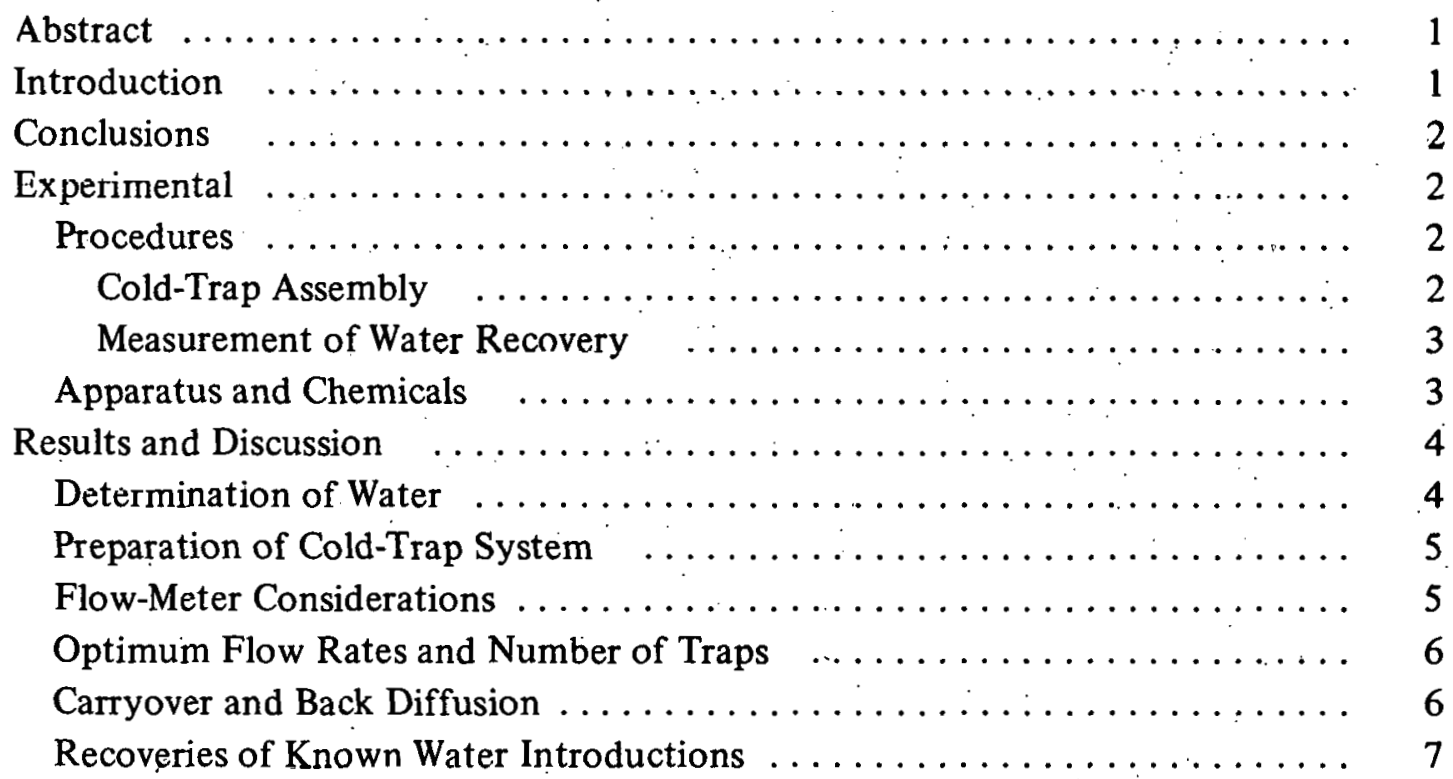

APPENDIX A. Laboratory Procedure for Cold-Trap Method $\ldots \ldots \ldots \ldots \ldots g$

Setup for the Sampling Systom $\ldots \ldots \ldots \ldots \ldots \ldots \ldots \ldots \ldots \ldots$

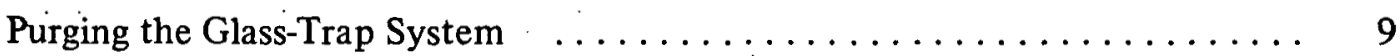

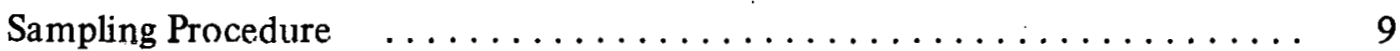

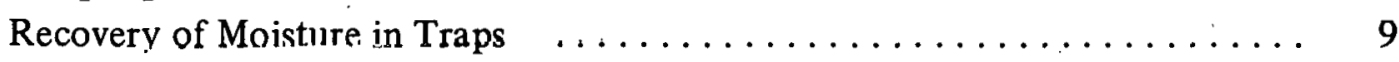

Determination of the Recovered Moisture $\ldots \ldots \ldots \ldots \ldots \ldots \ldots \ldots, 10$

Calculation of the Moisture Content in Gas $\ldots \ldots \ldots \ldots \ldots \ldots \ldots .10$ 


\section{ACKNOWIEDGMENTS}

The author is indebted to D. D. Long of the Product Group, Research and Ecology, for suggestions of experimental design and patience during the course of the investigations. Thanks are' expressed also to the following group personnel: E. B. Casillas for the skill, suggestinns, initiative, and application in carrying out the development work and for aid in drafting a workable laboratory procedure; to M. L. Ralston and M. N. Langley for skillful help and suggestions; to H. E. Norman for application of the method to the calibration of automated moisture analyzers; to J. R. Turbett for patience and encouragement; and to E. D. Ruby for editorial help with the text. 
RFP-1974

\title{
QUANTITATIVE DETERMINATION OF MOISTURE BY THE COLD-TRAP METHOD
}

\author{
Roger S. Cichorz
}

Abstract. The cold-trap method for determining moisture contents of atmospheric samples has been investigated and optimum sampling parameters determined. The method involves passing a known volume of test atmosphere through a series of glass traps immersed in a trichloroethylene dry-ice bath, thereby freezing out moisture in the trap. After the sampling period, the moisture was determined by a differential infrared spectrophotometric technique. The moisture content of the atmosphere then was calculated from the water recovery and volume of atmosphere tested.

Detailed are the results of the investigations and a critical examination of a refincd cold-trap method.

\section{INTRODUCTION}

The cold-trap method has been used at Rocky Flats Plant for several years to determine the moisture present in dry-box atmospheres. The method involves passing a known volume of the atmosphere to be tested through a series of glass traps immersed in a trichloroethylene dry-ice bath, thereby freezing moisture in the trap. After the testing period, the moisture is recovered by dissolution in anhydrous acetone and measured by a differential infrared spectroscopic technique. The nluislure content of the atmosphere can be calculated from the determined water recovery and the volume of atmosphere tested.

The cold-trap method can be adapted to determine a wide range of moisture contents in atmospheres of varied compositions. Three requirements must be met by a given atmosphere before the moisture content can be determined by this method:

(1) The density and average molecular weight of the atmosphere must be known; (2) The atmosphere must not interfere with the method. Corrosive atmospheres, notably those con taining hydrogen fluoride (HF), will cause physical damage to testing apparatus. Atmospheres cannot be tested if they contain materials which, when condensed, will interfere with the infrared-spectroscopic detection of water. Such interferences generally are organic materials con taining hydroxy gromps which absorb in the same spectral regions as water; and
(3) Enough sample atmosphere must be available to trap 0.5 microliters $(\mu \mathrm{l})$ of water $\left(\mathrm{H}_{2} \mathrm{O}\right)-$ the minimum amount of moisture that can be detected by the differential infrared spectroscopic determination. For example, to detect the moisture content in air containing water at 50 parts per million by volume $\left(\mathrm{ppm}_{\mathrm{v}}\right)$ at $25^{\circ} \mathrm{C}$ and 610 millimeters of mercury $(\mathrm{mm} \mathrm{Hg}), 100$ liters of sample must be available. (For metric use: the term millimeters of mercury $(\mathrm{mm} \mathrm{Hg})$ at $0^{\circ}$ has been changed by international agreement to 133 pascals.)

The cold-trap method as originally developed employed a single trap to recover moisture and a wet-test meter to measure the volume of atmosphere sampled. The accuracy and precision of the method were both reported to be about \pm 5 percent for water. ${ }^{1}$ The cold-trap method was chosen as a standard for determining the moisture content in Rocky Flats dry-box systems, for the purpose of calibrating several commercial moisture analyzers. ${ }^{2}$ The coldtrap method was examined critically and found unreliable. A single-trap sampling system would not recover moisture quantitatively. The wet-test meter was sufficiently inaccurate, and the Standards Laboratory group would not rertify it to within \pm 10 percent of the manufacturer's calibrated value.

The need for refining the cold-trap method was appátenl. Testing programs were developed to examine the experimental parameters and to assess which sampling conditions ultimately would lead to a rapid, accurate, and precise cold-trap method. Several areas were examined in detail:

1. Determining flow-rate accuracy and precision.

2. Preparing and purging the cold-trap system.

3. Preparing and assessing precision of the Beer-Lambert calibration plots used in the infrared spectroscopic determination of water.

\footnotetext{
${ }^{1}$ L, F, Grill. Intemal Private Cummunication. 1966.

${ }^{3}$ D. D. Long. "Low-Ḧumidity Test Measurements." Instrument Society of America Transactions, 8:71. 1969.
} 
4. Assuring quality performance of the infrared spectrophotometer.

5. Determining optimum sampling rates and number of traps for water recovery.

6. Determining the effect of water carryover and back diffusion.

\section{CONCLUSIONS}

Of the experimental parameters examined in the reported cold-trap method investigations, the infrared spectroscopic determination of water, the measured flow rates of the calibrated flow meters, and the performance of the infrared spectrophotometer all have a relative precision of better than five percent. Two variables - the actual flow rate and number of traps employed in the sampling system - appear most critical to the method.

The optimum flow rate is between 200 and 450 cubic centimeters per minute $\left(\mathrm{cm}^{3} / \mathrm{min}\right)$. Below $200 \mathrm{~cm}^{3} / \mathrm{min}$ flow rate, back diffusion of moisture into the final collecting trap becomes appreciablc. However it can be eliminated by employing a drying tube charged with silica gel on the exhaust port of the final trap of the series. Above 400 $\mathrm{cm}^{3} / \mathrm{min}$, moisture carryover is appreciable from the first trap in series to the second, from the second to the third, and finally from the last trap out of the sampling system. Thus luw analytical results are obtained. The flow rate of $400 \mathrm{~cm}^{3} / \mathrm{min}$ is chosen because it lies at the maximum end of the optimum range.

A single-trap system is not reliable and leads to low results because of passage of moisture from the system. Less than 90-percent recoveries and relative standard deviations of greater than 10 percent are experienced with a one-trap system. Although unfit for precise analytical work the system is sufficient for obtaining preliminary data, i.e., estimating moisture contents.

A two-trap system, operating within the optimum ranges of air-flow rate, will yield better than 95 percent recoveries ( 96 to 98 percent on known water introductions) with relative standard deviations of less than 10 percent. The two-trap setup is sufficient for most analytical work. The moisture carryover and back-diffusion factors cancel out one another and have been eliminated from further consideration.

A four-trap system, operating within the optimum ranges of air-flow rate, yields essentially quantitative recoveries (98 to 102 percent on known water introductions) with relative standard deviations of 5 percent or less. The four-trap setup appears best suited for accurate and precise analy tical work, but is more tedious than the two-trap system, because of the additional plumbing and analysis time involved.

The major advantages of the cold-trap method are accuracy and reliahility. Another advantage of the cold-trap method is the relative independence of the moisture content of the atmosphere being analyzed. Once preliminary data (via a single-trap or automated-moisture analyzer) are obtained, the sampling time can be adjusted to trap moisture in the optinum analysis concentration range.

The major disadvantage of the method is the time involved in analysis, which includes apparatus setup, purging, sampling, moisture recovery and determination, and lengthy calculations. Another limitation in the method is the application mainly to relatively statir systems. The method gives a mean water content nver the duration of the sampling period. Therefore for systems of widely fluctuating-moisture contents, the accuracy of the method dccreases with increasing sampling time.

\section{EXPERIMENTAL}

Procedures: The current laboratory procedure for the cold-trap method lias been de tailcd in $\Lambda$ ppendix A, Page 9.

COLD-TRAP ASSEMBLY - For atmospheric sampling, two to four cold traps are connected in series to a laboratory pump and precision flow meter. The traps are purged of traces of moisture, then directly vented to the atmosphere to be tested. A schematic of the experimental sampling setup is shown in Figure 1.

For moisture-recovery investigations, the traps are connected to a source of carrier gas such as nitrogen 


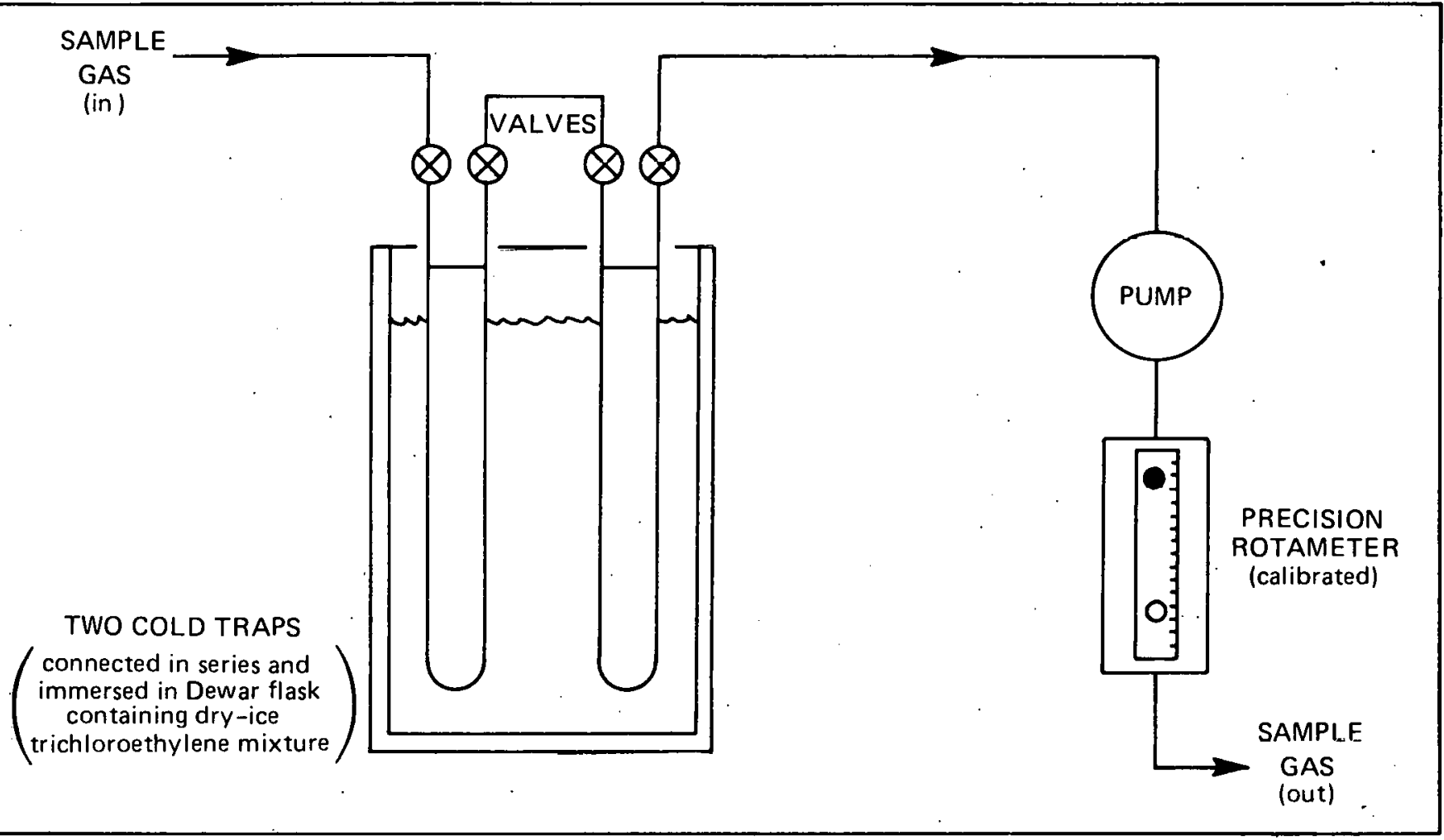

FIGURE 1. Cold-Trap Method for Moisture in Gas or Air.

$\left(\mathrm{N}_{2}\right)$ or helium $(\mathrm{He})$, the moisture content of which has been either predetermined or removed by a cold-trap subassembly. Between the carrier-gas source and cold-trap assembly is inserted an airtight moisture introduction chamber. The chamber contains a self-sealing septum which permits water introduction via a calibrated syringe.

For moisture-analyzer calibration work, an airtight moisture element chamber is connected between the moisture-introduction chamber and the cold-trap assembly. The schematic of the system is depicted in Figure 2.

\section{MEASUREMENT OF WATER RECOVERY -} Moisture collected in the cold trap is recovered in 3-milliliter $(\mathrm{ml})$ anhydrous acetone and quickly transferred to one of a matched pair of $10.0-\mathrm{mm}$ near infrared (NIR) silica cells and stoppered. The cell is placed in the path of the sample beam of the infrared spectrophotometer. The other matched cell is filled with anhydrous acetone, stoppered, and placed in the path of the reference beam of the infrared spectrophotometer. The water content of the acetone in the path of the sample beam is determined by scanning the (water) $\mathrm{H}_{2} \mathrm{O}$ - combination band at about 1.94 micrometers $(\mu \mathrm{m})$ or the $\mathrm{H}_{2} \mathrm{O}$-overtone band at about $1.43 \mu \mathrm{m}$. The respective absorbances of the bands are measured by the empirical baseline method and correlated to water concentrations by means of previously prepared Beer-Lambert calibration plots. The moisture content of the atmosphere tested then is calculated from the measured water recovery and known sampling conditions.

\section{Apparatus and Chemicals:}

1. Glass (Pyrex® or Kimax) cold traps. The traps, which are of unit construction with straight-center stem design and dual-Teflon® stopcock assembly, are fabricated from commercially available glass-vacuum traps.

2. Precision-flow meter units, 50 to $600 \mathrm{~cm}^{3} / \mathrm{min}$ range, The Matheson Company, Incorporated, East Rutherford, New Jersey.

3. Teflon connectors, T-joints, and tape.

4. Laboratory vacuum pump, Model-2 Dyna Pump, Neptune Products Company, Glendale, New York. 


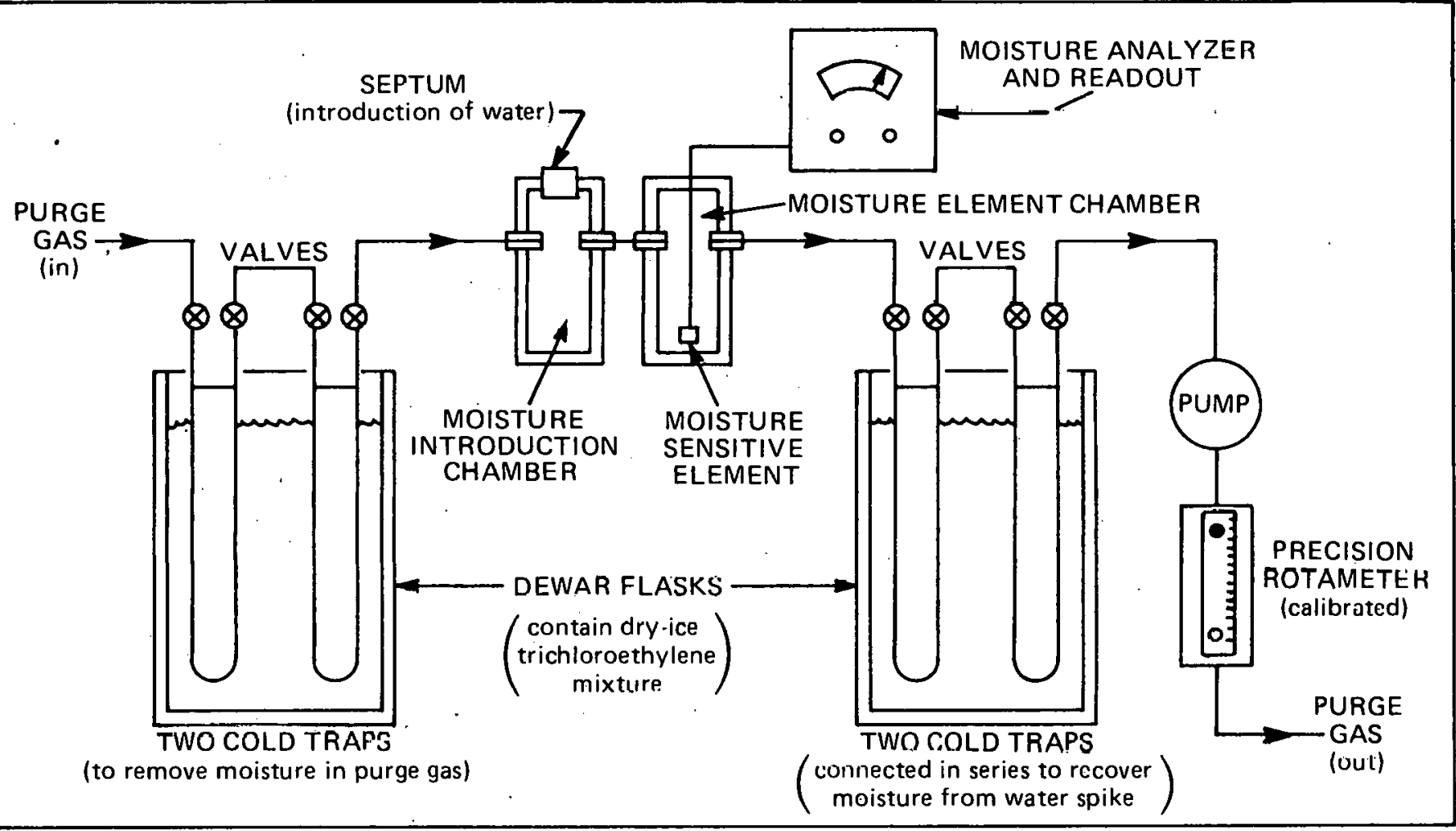

FIGURE 2. Cold-Trap Method for Calibration of Moisture Analyzer.

5. Thermos ${ }^{\circledR}$, Pyrex $®$ glass-vacuum bottle, 1900-milliliter capacity.

6. Flameless heat gun, hand-portable, 200 to $300^{\circ} \mathrm{F}$ range.

7. Dry ice.

8. Trichloroethylene. Alk-Tri® Grade, Dow Chemical U.S.A., Midland, Michigan.

9. Anhydrous acetone. Baker Analyzed, Spectrophotometric Quality Acetone, J. T. Baker Chemical Company, Phillipsburg, New Jersey. This reagent contains 0.05 percent water and is dried and stored over Linde Molecular Sieve, Type-4A, Matheson Coleman and Bell, East Rutherford, New Jersey.

10. Matched, rectangular 10.0-millimeter pathlength near infrared silica cells with groundglass. stoppers, Beckman Instrument Corporation, Fullerton, California.

11. Cylinder, nitrogen $\left(\mathrm{N}_{2}\right)$ gas.
12. Cylinder, helium (He) gas.

13. Perkin-Eliner, 137-G Infraoord recording spectrophotometer, Perkin-Elmer Corporation, Nur walk, Cunnecticut.

14. Chart paper: 0.90 to 2.5 -micrometer range, absorbance, linear-wavelenthli, Peikin-Elmor Corporation.

15. Microliter syringes, various capacities, scale accuracies, and sample reproducibilities rated at 1-percent relative, Hamilton Corporation, Whittier, California.

\section{RESULTS AND DISCUSSION}

Determination of Water: The Beer-Lambert calibration plots of absorbance versus water concentration were prepared by introducing known amounts of water into 3-ml anhydrous acetone. Lambda micropipets and Hamilton microsyringes with specified accuracy and precision of 1-percent relative of volumes delivered were used to make the 
introductions. The standard solutions were housed in the 10.0-mm NIR cells and measured differentially against anhydrous acetone at 1.43 and $1.94 \mu \mathrm{m}$, respectively the water-overtone and water-

combination bands.

The lower limit of water detection at 1.94 micrometers is 0.5 microliters $(\mu \mathrm{l})$ of water $\left(\mathrm{H}_{2} \mathrm{O}\right)$ per 3 milliliters of acetone. The upper limit is greater than $15 \mu \mathrm{l}$ of water per $3 \mathrm{ml}$ of acetone. The calibration plot is linear over this range. The lower detection limit at $1.43 \mu \mathrm{m}$ is $5 \mu \mathrm{l}$ of $\mathrm{HI}_{2} \mathrm{O}$ per $3-\mathrm{mi}$ acetone, and the upper limit is greater than $200 \mu 1$ of $\mathrm{H}_{2} \mathrm{O}$ per $3 \mathrm{ml}$ of acetone. The plot is linear over the 5 to $7 \mu 1$ of $\mathrm{H}_{2} \mathrm{O}$ per $3-\mathrm{ml}$ acetone range. The quantity, 3-ml acetone, is chosen for this work because it will essentially bring the liquid level in a $10.0-\mathrm{mm}$ rectangular cell to a point which will insure complete spectrophotometer beam passage. In addition, it is easily measured to within 1-percent relative accuracy and precision by conventional pipetting.

In preparing the Beer-Lambert calibration plots, triplicate standards were prepared and measured. Over the linear calibration range, replicate standards yielded experimental results of better than 2percent relative precision. The infrared data are given in Table I.

During the investigation, two control studies were performed on the infrared spectrophotometer to assure reliable instrumentation. Scans of Alk-Tri@ grade trichloroethylene in a $10-\mathrm{mm}$ NIR cell were made prior to each series of moisture determinations, and several absorbance bands in the grating region of interest were measured. The absorbances agreed within 2 to 3 percent relative to the absorbances obtained from the previous determination. The agreement indicated proper instrument functioning with no significant loss of energy through faulty detector or source components. The second set of control studies involves monthly checks with a polystyrene film standard. Scans over a 20-month period (January 1968 to September 1969) have indicated less than 5-percent relative standard deviation at two selected absorbance levels:

$$
\begin{array}{ll}
\text { mean absorbance } & =0.392 \\
\text { standard deviation } & =0.0194 \\
\text { relative precision } & =4.96 \text { percent } \\
\text { mean absorbance } & =0.724 \\
\text { standard deviation } & =0.0320 \\
\text { relative precision } & =4.35 \text { percent }
\end{array}
$$

In addition, standards are prepared periodically to check the reliability of the present Beer-Lambert calibration plots.

The instrument control studies indicate that no greater than 5-percent relative deviation of results on successive trials should be anticipated from infrared measurements. This is in good agreement with the 4 to 5 percent relative limit generally assessed to series of quantitative infrared measurements.

Preparation of Cold-Trap System: The cold-trap apparatus was set up and purged with nitrogen passed through a cold-trap subassembly, as described in the laboratory procedure in Appendix A, Page 9. No moisture was detected in any of the traps

\begin{tabular}{|c|c|c|c|}
\hline (ıiictumeters) & $\left(\begin{array}{c}\text { Detectiun Range } \\
\text { microliters of water } \\
\text { per } \\
3 \text { milliliters of acetone. }\end{array}\right)$ & *Absorptivity & $\begin{array}{l}\text { Relative Precision } \\
\text { Standard Deviation }\end{array}$ \\
\hline $1.43\left(\mathrm{H}_{2}\right.$ O-overtone $)$ & 5 to 200 & $4.27 \times 10^{-3}$ & Better than 2 percent over linear detection range \\
\hline $1.94\left(\mathrm{H}_{2} \mathrm{O}\right.$-combination $)$ & 0.5 to 15 & $4.57 \times 10^{-2}$ & Better than 2 percent over entire detection range \\
\hline
\end{tabular}
examined. Hence, no significant blank had to be considered in these investigations.

Flow-Meter Considerations: The Matheson flow meters employed in the investigation were rated at

TABLE I. Summary of Infrared Spectrophotometric Determination of Water.

*Absorptivity units are reciprocal centimeters $\left(\mathrm{cm}^{-1}\right) \times$ (reciprocal microliters of water per 3 milliliters of acetone). The absorptivity was determined by least-squares treatment of data in linear Beer-Lambert range. 
an accuracy of \pm 2 -percent full scale. However, the Rocky Flats Standards Laboratory calibrated these to a tolerance of only $\pm 25 \mathrm{~cm}^{3} / \mathrm{min}$ full scale.

To assess the relative precision of delivery of two flow meters, the flow rates of two meters were regulated to pass atmosphere corresponding to identical flow rates from the manufacturer's cali- . bration curves. When the flow rates of the two meters tested were regulated in such a way as to have specified equal flow rates, simultaneous 30minute sampling periods for mositure recovery from air were undertaken. The difference in moisture recovery, if significant, would reveal flowrate differences between the two meters. It was found that the relative difference between the two flow meters at $230 \mathrm{~cm}^{3} / \mathrm{min}$ and $462 \mathrm{~cm}^{3} / \mathrm{min}$ rates was less than 4 percent, or within the accuracy of the spectrophotometric moisture determination.

It was concluded that the differences in calibrated flow rates between flow meters in the flow-rate ranges tested are not significant. The ultimate accuracy of the flow rates could be assessed during the recovery studies when the total volume of atmosphere tested becomes a major factor in the calculations. The data from the flow-meter rate comparisons are suminarizcd in Table II.

\section{Optimum Flow Rates and Number of 'I raps:'}

Two-hour sampling periods of laboratory air, containing an order of $\supset U \cup \dot{0} \mathrm{ppm}_{\mathrm{v}}$ wales wese made at varying flow rates on a four-trap system. Water recoveries were determined for each trap and normalized for 100-percent recovery to assess optimum flow rates. No apparent differences of water carryover or back diffusion into 'I'raps 3 and 4 were determined for the 120 to $400 \mathrm{~cm}^{3} / \mathrm{min}$ flow rates. At $500 \mathrm{~cm}^{3} / \mathrm{min}$, carryover to Traps 2,3 , and 4 was significant on the first of two runs. Hence, the $400 \mathrm{~cm}^{3} / \mathrm{min}$ flow rate was chosen as the maximum optimum-sampling ratc. The data for these trials are summarized in Table III.

The carryover back diffusion of moisture in Traps 3 and 4 did not appear to be significant (less than 1.5-percent total moisture recovcred), so that a two-trap system seemed feasible. The total moisture recovery in a two-trap system ranged only from 97.48 to 99.13 percent in the 200 to $400 \mathrm{~cm}^{3} / \mathrm{min}$ flow-rate range. A one-trap system had too wide a recovery variance for a given flow rate to be satisfactory for accurate determinations.

Carryover and Back Diffusion: The problem at this point in the investigation was to ascertain whether the water recovered in Traps 3 and 4 resulted from carryover, which would lead to low analytical results on a two-trap system, or moisture back diffusion, which would lead to high analytical results on a two-trap system, or a combination of both factors. To expedite the investigation, the two-trap system was examined.

Rack diffusion of moisture could be eliminated by charging the exil port of the last trap with a silicagel drying tube. Over the flow rates examined, the waler recovercd in a cecond trap was slightly greater for the system which employed the silicagol drying tube, hut the difference of 0.5 percent was within the experimental variation expected for the method. No significant back diffusion was indicated. It appeared that moisture carryover from the second trap and back diffusion into the secund trap roughly cancel out one annther. Results are summarized in Table IV.

TABLE II. Flow Meter Comparisons of Simultanenus Trials with Air.

\begin{tabular}{|c|c|c|c|c|c|}
\hline $\begin{array}{l}\text { Flow Meter } \\
\text { No. }\end{array}$ & $\begin{array}{l}\text { Time of Trial } \\
\text { (minutes) }\end{array}$ & $\begin{array}{c}\text { Calibrated Flow Rate } \\
\text { (cubic centimeters per minute) }\end{array}$ & $\begin{array}{l}\text { Recovery } \\
\text { (microliters of water) }\end{array}$ & $\begin{array}{c}\text { Difference } \\
\text { (microliters of water) }\end{array}$ & $\begin{array}{l}\text { Relative Difference } \\
\text { (percent) }\end{array}$ \\
\hline 1 & 30 & 462 & 153 & 5. & 3.3 \\
\hline 1 & 30 & 230 & 85.5 & \multirow[t]{2}{*}{1.7} & \multirow[t]{2}{*}{2.0} \\
\hline 2 & 30 & 230 & 83.8 & & \\
\hline
\end{tabular}


Recoveries of Known Water Introductions:

For the experimental parameters (e.g., calibration plot accuracy and precision, flow-rate precision) in the optimum flow-rate range, a precision of better than 5 relative percent is anticipated for a two-trap system. Assuming flow-rate accuracy is within 2 to 3 relative percent as specified by the manufacturer, a method accuracy of within 5 relative percent also is anticipated.

Method accuracy was determined by recoveries of known water introduction. The water introductions were made by microliter syringe injections through a septum in an air-tight sample chamber (see Figure 2). The purge gas, nitrogen containing less than $50 \mathrm{ppm}_{\mathrm{v}} \mathrm{H}_{2} \mathrm{O}$, was dried by passing it through a preliminary two-trap system.

TABLE III. Flow Rate versus Moisture Recovery on Four-Trap System.

\begin{tabular}{|c|c|c|c|c|c|}
\hline \multirow{2}{*}{$\begin{array}{c}\text { Flow Rate } \\
\left(\begin{array}{c}\text { cubic } \\
\text { centimeters } \\
\text { per minute }\end{array}\right)\end{array}$} & \multicolumn{5}{|c|}{ Percent Water Collected } \\
\hline & Trap 1 & Trap 2 & Trap 3 & Trap 4 & Traps $1+2$ \\
\hline 120 & 95.38 & 2.10 & 0.50 & 2.02 & 97.48 \\
\hline $\begin{array}{l}200 \\
200\end{array}$ & $\begin{array}{l}93.78 \\
97.23\end{array}$ & $\begin{array}{r}3.94 \\
.2 .07\end{array}$ & $\begin{array}{l}0.48 \\
0.33\end{array}$ & $\begin{array}{l}0.59 \\
0.37\end{array}$ & $\begin{array}{l}97.72 \\
99.30\end{array}$ \\
\hline $\begin{array}{l}300 \\
300\end{array}$ & $\begin{array}{l}93.45 \\
95: 94\end{array}$ & $\begin{array}{l}5.15 \\
2.92\end{array}$ & $\begin{array}{l}0.88 \\
0.41\end{array}$ & $\begin{array}{l}0.52 \\
0.73\end{array}$ & $\begin{array}{l}98.60 \\
98.86\end{array}$ \\
\hline $\begin{array}{l}400 \\
400\end{array}$ & $\begin{array}{l}94.45 \\
96.36\end{array}$ & $\begin{array}{l}4.22 \\
2.77\end{array}$ & $\begin{array}{l}1.06 \\
n 7 n\end{array}$ & $\begin{array}{l}0.27 \\
0.17\end{array}$ & $\begin{array}{r}98.67 \\
99.13\end{array}$ \\
\hline $\begin{array}{l}500 \\
500\end{array}$ & $\begin{array}{l}90.03 \\
94.99\end{array}$ & $\begin{array}{l}6.71 \\
4.03 \\
\end{array}$ & $\begin{array}{l}2.17 \\
0.72 \\
\end{array}$ & $\begin{array}{l}1.09 \\
0.26 \\
\end{array}$ & $\begin{array}{r}96.74 \\
99.02 \\
\end{array}$ \\
\hline *cumulative & 94.64 & 3.89 & 0.90 & 0.57 & 98.53 \\
\hline
\end{tabular}

*Cumulative results determined from total collection of moisture in Traps 1, 2, 3, and 4.
No water could be detected in the nitrogen that had been treated in this manner. The nitrogen flow would essentially empty the sample chamber of moisture within 15 minutes, and the moisture collected in the traps could be determined by the method previously described.

In the four-trap system, quantitative water recovery was obtained for a 16 to 256 -microliter range of water introductions. Recovery in a two-trap system resulted in about 2 to 3 percent less, although one low determination in each of the three introduction ranges was largely responsible for this lower recovery. A summary of the method recoveries is given in Table $\mathrm{V}$.
TABLE IV. Flow Rate versus Moisture Recovery on Two-Trap System.

\begin{tabular}{|c|c|c|c|c|}
\hline \multirow{3}{*}{$\left(\begin{array}{c}\text { Flow Rate } \\
\text { centimeters } \\
\text { per } \\
\text { minute }\end{array}\right)$} & \multicolumn{2}{|c|}{$\begin{array}{l}\text { Silica-Gel Drying } \\
\text { Tube on Exhaust }\end{array}$} & \multicolumn{2}{|c|}{$\begin{array}{l}\text { No Silica-Gel } \\
\text { Drying Tube }\end{array}$} \\
\hline & \multicolumn{2}{|c|}{ Percent Water Collected } & \multicolumn{2}{|c|}{ Percent Water Collected } \\
\hline & Trap 1 & Trap 2 & Trap 1 & Trap 2 \\
\hline 115 & $\overline{98.88}$ & 1.12 & - & - \\
\hline 172 & 98.95 & 1.05 & - & - \\
\hline 230 & 98.56 & 1.14 & 98.85 & 1.15 \\
\hline 287 & 96.43 & 3.5 .7 & 99.08 & 0.92 \\
\hline 345 & 98.42 & 1.58 & 97.95 & 2.05 \\
\hline 403 & 97.32 & 2.68 & 97.64 & 2.36 \\
\hline 461 & 94.07 & 5.93 & 97.34 & 2.66 \\
\hline 518 & 91.00 & 9.00 & 91.79 & 8.21 \\
\hline${ }^{*}$ cumulative & $\overline{96.74}$. & $\overline{3,26}$ & $\overline{97.23}$ & 2.77 \\
\hline
\end{tabular}

*Cumulative results determined from total collection. of moisture in Traps 1 and 2.

TABLE V. Summary of Cold-Trap Method Recoveries.

\begin{tabular}{|c|c|c|c|c|c|c|}
\hline System & $\begin{array}{c}\text { Number of } \\
\text { Trials }\end{array}$ & $\begin{array}{c}\text { Water Added } \\
\left(\begin{array}{c}\text { parts per million by } \\
\text { volume of water }\end{array}\right)\end{array}$ & $\begin{array}{c}\text { Mean Kecovery } \\
\left(\begin{array}{c}\text { parts per million by } \\
\text { volume nf water }\end{array}\right)\end{array}$ & $\begin{array}{l}\text { Percent } \\
\text { Recovery }\end{array}$ & $\begin{array}{c}\text { Standard } \\
\text { Deviation } \\
\left(\begin{array}{c}\text { parts per million by } \\
\text { volume of water }\end{array}\right)\end{array}$ & $\begin{array}{r}\text { Relative } \\
\text { Precision } \\
\text { (percent) }\end{array}$ \\
\hline Two Traps & 4 & 8812 & 8496 & 96.4 & 529 & 6.23 \\
\hline Four Traps & 4 & 8812 & 8652 & 98.2 & 436 & 5.04 \\
\hline Two Traps & 3 & 2203 & 2160 & 98.0 & 191 & 8.84 \\
\hline Four Traps & 3 & 2203 & 2236 & 101.5 & 64 & 2.91 \\
\hline Two Traps & 3 & 551 & 539 & 97.8 . & 31 & 5.75 \\
\hline Four Traps & 3 & 551 & 551 & 100.0 & 9 & 1.65 \\
\hline
\end{tabular}

Conditions: 30 or 60-minute trials; Nitrogen $\left(\mathrm{N}_{2}\right)$ carrier gas at 400 cubic centimeters per minute. 
RFP-1974 
APPENDIX A. Laboratory Procedure for Cold-Trap Method.

The current laboratory procedure for the coldtrap method follows.

\section{Setup for the Sampling System:}

The traps ( 2 to 4 in series) are connected by means of Teflon connectors. Teflon tape is applied to the openings of the traps to act as a seal between the traps and connectors. A Teflon tube is connected to the entry arm of the first trap in the series; this is connected to the appropriate sample source (gas-cylinder outlet, inlet to dry-box system, etc.). The exit arm of the last trap in series is connected with a Teflon or Tygon tube, which is connected to the vacuum pump inlet. The pump outlet is connected by means of Teflon or Tygon tubing to the flow meter. Teflon tape is used to seal all connections.

\section{Purging the Glass-Trap System:}

Prior to immersing the glass traps in the trichloroethylene dry-ice bath, the system must be purged with helium to remove traces of residual muisture. The traps are heated at about $150^{\circ} \mathrm{C}$ with the flameless heat gun for five minutcs while being purged with a gas flow of greater than 1000 subic centimeters per minute $\left(\mathrm{cm}^{3} / \mathrm{min}\right)$. The leat is removed and the gas purge is continued or 15 minutes while the traps return to room temperature.
The inlet and exit stopcocks of the trap series should be closed while the system is being connected to the sampling source to prevent diffusion of moisture from outside. Traps purged according to this procedure are free of residual moisture.

\section{Sampling Procedure:}

The glass-trap system is connected to the sampling source and the trap stopcocks are opened. The gas from the test site is passed through the system for five minutes to allow it to reach equilibrium. The flow rate of gas should be adjusted to $400 \mathrm{~cm}^{3} / \mathrm{min}$, which is the experimentally determined optimum rate. The sampling begins when the traps are immersed in the cold bath. The trap shut-off valves must be maintained above the bath to prevent water from entering through leaks in the stopcock system.

The experiment must be timed from start to finish in order to determine the total volume of gas that flowed through the system. The experiment starts when the traps are immersed in the cold baths and ends when the pump is shut off and the trap stopcocks are closed. A sampling time of 30 minutes is sufficient for most samples:

\section{Recovery of Moisture in Traps:}

The traps are renioved from the cold bath, the stopcocks closed, and the system disassembled. 
The traps are allowed to warm to room temperature (about 20 minutes). Three milliliters of anhydrous acetone are introduced into each trap. The traps are shaken vigorously to get the moisture into solution with the acetone.

The acetone from the first trap is transferred to one of the matched rectangular 1-centimeter near infrared (NIK) silica cells designated as thc sample cell, and the cell is stoppered immediately. The other matched cell, designated the reference cell, is filled with anhydrous acetone and stoppered immediately.

\section{Determination of the Recovered Moisture:}

The water absorbance is measured differentially at 1.43 or 1.94 micrometers. The sample cell is placed in the sample beam of the P-E 137-G Infracord and the reference cell is placed in the reference beam. The instrument is allowed to scan slowly over the 1.38 to 1.48 -micrometer range or 1.87 to 1.97 -micrometer range and the spectrum recorded.

The absnrhanre of the 1.43 or 1.94 -micrometer band is measured hy the baseline method, and the water concentration determined from the appropriate Beer-Lambert calibration plots.

The two steps above are repeated for each trap in the system.

\section{Calculation of the Moisture Content in Gas:}

The concentration of water in the gas sample is calculated from the amount of water $\left(\mathrm{H}_{2} \mathrm{O}\right)$ recovered in the acetone. Conversion to $\mathrm{H}_{2} \mathrm{O}$ concentration in gas involves several variables, such as temperature and pressure at the time of the experiment. (a) Parts per million by volume:

$$
\begin{gathered}
\operatorname{ppm}_{\mathrm{v}}=\frac{\mathrm{W} \times 10^{6} \times \mathrm{M}_{\mathrm{g}}}{\mathrm{V} \times \mathrm{D}_{\mathrm{c}} \times \mathrm{M}_{\mathrm{W}}} \\
\mathrm{W}=\begin{array}{l}
\text { total water }\left(\mathrm{H}_{2} \mathrm{O}\right) \text { in milliliters }(\mathrm{ml}) \\
\text { recovered in traps }
\end{array} \\
\mathrm{V}=\text { volume of gas sampled in liters } \\
\mathrm{D}_{\mathrm{C}}=\begin{array}{l}
\text { gas density (corrected to experimental } \\
\text { temperature and pressure): }
\end{array} \\
\mathrm{D}_{\mathrm{c}}=\mathrm{D} \times \frac{273.16}{273.16+\mathrm{T}} \times \frac{\mathrm{B}}{760}
\end{gathered}
$$

Where,

$$
\begin{aligned}
& \mathrm{D}=\text { density of gas sample at standard } \\
& \text { temperature and pressure, }\left(\mathrm{T}-{ }^{\circ} \mathrm{C}\right) \\
& \text { B = millimeters of mercury at time of } \\
& \text { experiment } \\
& \mathrm{M}_{\mathrm{g}}=\text { molecular weight of the gas sampled } \\
& \text { [e.g., } 28.966 \text { for air; } 28.013 \text { for } \\
& \text { nitrogen }\left(\mathrm{N}_{2}\right) \text { ] } \\
& \mathrm{M}_{\mathrm{W}}=\text { molecular weight of water (18.02) }
\end{aligned}
$$

For air sampling,

D 1.2029 grnma par liter at standard temperatures and pressure and the conversion formula is simplified to:

$$
\operatorname{ppm}_{\mathrm{v}}=\frac{\mathrm{W}(945.00+3.46 \mathrm{~T}) \times 10^{6}}{\mathrm{~V} \mathrm{~B}}
$$

(b) Parts per million by weight:

$$
\mathrm{ppm}_{\mathrm{W}}=\frac{\mathrm{W} \times 10^{6}}{\mathrm{~V} \times \mathrm{D}_{\mathrm{c}}}
$$

For air sampling,

$$
\begin{aligned}
\mathrm{D}= & 1.2929 \text { grams per liter at standard tem- } \\
& \text { perature and pressure and the conversion } \\
& \text { formula is simplified to: }
\end{aligned}
$$

$$
\mathrm{ppm}_{\mathrm{W}}=\frac{\mathrm{W}(2076+7.6 \mathrm{~T}) \times 10^{6}}{3.53 \mathrm{~V} \mathrm{~B}}
$$

